\title{
Effects of Different Levels of Copper Sulfate on Growth and Reproductive Performances in Guppy (P. reticulate)
}

\section{Mahsa Javadi Moosavi ${ }^{1 *}$ and Vali-Allah Jafari Shamushaki ${ }^{2}$}

${ }^{1}$ M.Sc Graduated of Aquaculture, Gorgan University of Agricultural Science and Natural Resources, Faculty of Fishery and Environmental Science, Golestan, I.R. Iran ${ }^{2}$ Assistance Professor, Department of Fisheries, Gorgan University of Agricultural Sciences and Natural Resources, Gorgan, Iran

\begin{abstract}
Adult Guppies (Poecilia reticulate) were exposed to copper sulfate $\left(\mathrm{CuSO}_{4} 5 \mathrm{H}_{2} \mathrm{O}\right)$ to evaluate the effects on growth, survival and reproduction performances. Total 480 individuals (mean age of 2.5-3 months) were employed in 5 experimental groups containing 16 fish per group and exposed to 4 sub-lethal levels of copper ( 0 as control, $0.004,0.013,0.019$ and $\left.0.026 \mathrm{mg} \mathrm{CuSO}_{4} . \mathrm{I}^{-1}\right)$ for a period of 56 days. Control group had relative advantage than experimental ones at both growth and reproduction performances. As the copper concentration increased, Relative fecundity, gonadosomatic index, surviving rate, offspring production and feed conversion ratio decreased but specific growth rate increased significantly $(P<0.05)$. Focused energy consumption in liver for $\mathrm{Cu}$ detoxification process and lack of energy for other physiological demands confirm low SGR and high FCR values in this study. It's obvious that copper has its toxic effects for guppy, even at lower concentrations than LC50 value (0.46 mg Cu..$\left.^{-1}\right)$
\end{abstract}

Keywords: Guppy; Copper sulfate; Growth performance; Reproductive performance

\section{Introduction}

Copper $(\mathrm{Cu})$ like other trace elements [zinc $(\mathrm{Zn})$, iron $(\mathrm{Fe})$, manganese $(\mathrm{Mn})$, etc. serves important functions in living cells and is essential for fish [1]. Copper sulfate $\left(\mathrm{CuSO}_{4}\right)$ is the sulfated form of copper which routinely used as an algicide in commercial and recreational fish ponds. It is generally recognized that copper can be highly toxic to teleosts $[2,3]$. In aquaculture, copper is being used as eternal parasites, bacterial and fungal disease preventer and also weeds cleaning in sulfated form [4]. The ideal concentration of copper sulfate for weed termination has been suggested to be as much as $1 \mathrm{mg} .1^{-1}$ in which has lower poisonous effect on fish but highly affects the invertebrates [5]. According to the records of United States Environmental Protection Agency (EPA), copper sulfate is an ordinary compound which is being used broadly in aquaculture. Moreover, the Food and Drug Administration (FDA) has barred the medicinal use of copper in aquaculture.

It should be considered that copper could be accumulated in water body and gradually increases the concentration will raise to lethal concentration for fishes [4]. Toxicity of copper to aquatic species depends on factors such as organism sensitivity, concentration of copper and its bioavailability [6], total hardness, $\mathrm{pH}$ [7], organic particles or various other inorganic cations and anions [8]. So it is notable to avoid using copper in waters with lower alkalinity than 50 $\mathrm{mg} \mathrm{CaCo} \mathrm{I}^{-1}$. The range of copper sulfate is in aquaculture as much as $0.025-2 \mathrm{mg}^{-1} \mathrm{l}^{-1}$ according to alkalinity and total hardness [9] but the usual effective use in aquaculture is reported as much as 0.01 of total alkalinity [10].

Guppy (P. reticulata) (or rainbow fish) is one of the most widely distributed tropical fish in the world. It is a member of the Poeciliidae family and, like all other members of the family, is live-bearing. Northeast South America is the native habitat for guppies but now, they could be found all around the world. High adaption ability makes them live in many different environmental and ecological conditions. Guppies exhibit sexual dimorphism and omnivorous feed habit (algal remains, diatoms, invertebrates, plant fragments, mineral particles, aquatic insect larva, etc.). Females produce offspring from first 10 weeks to 34 months of age, but first reproduction occur in 10-20 weeks of age. They are used as a model organism in the field of ecology, evolution, and behavioral studies [11]. Due to copper sulfate therapeutic trait which made it an ordinary drug for use in ornamental fish's hatcheries and personal aquariums despite its toxic effects and shortage of focused study on reproductive performance in guppy (P. reticulate), this study carried out.

\section{Methods and Materials}

This study performed at the aquatic laboratory of Shahid Fazli Bar Abadi located in Gorgan university of Agricultural Science and natural Resources, Golestan, Iran. Experimental fishes were bought from a local hatchery (Shast Kolah road, Gorgan province, Iran). Upon arrival, 480 individuals of 2.5-3 months aged guppies were acclimated to laboratory conditions for 2 weeks in a $1000 \mathrm{~L}$ round fiberglass tank measuring $1 \mathrm{~m}$ in diameter and fed a commercial diet $(0.5-0.8 \mathrm{~mm}$ in size, Pars Kilka Corp, Babolsar, Iran) as much as $3 \%$ of body weight twice a day with two equal meals at 0800 and $1700 \mathrm{~h}$. The experiment was conducted in a completely randomized design with six replications per treatment for 56 days. At the beginning of the experiment, 16 fish $(\mathrm{N}$ : 12 female and 4 male; mean length: $3.59 \pm 0.11 \mathrm{~cm}$; mean weight: $0.36 \pm 0.01 \mathrm{~g})$ were stocked in each aquarium $(50 \times 35 \times 30 \mathrm{~cm})$ designed to contain $35 \mathrm{~L}$ tap water ( $\mathrm{pH}$ : $7.4 \pm 0.12$; salinity; $0.35 \pm 0.12 \mathrm{ppt}$; DO: $7.36 \pm 0.98 \mathrm{mg} . \mathrm{l}^{-1}$; total hardness: $270-300 \mathrm{mg} . \mathrm{l}^{-1} \mathrm{CaCO}_{3}$ ) and equipped with airstones to maintain dissolved oxygen levels as much as possible. The water temperature was kept $28 \pm 1^{\circ} \mathrm{C}$ by electrical heaters. Water quality variables were checked daily. Handmade plastic Happas were

*Corresponding author: Mahsa Javadi Moosavi, M. Sc Graduated of Aquaculture, Gorgan University of Agricultural Science and Natural Resources, Faculty of Fishery and Environmental Science, Golestan, I.R. Iran, Tel: 880-171-2141273; E-mail: javadimoosavi@gmail.com

Received November 28, 2014; Accepted December 16, 2014; Published January 18,2015

Citation: Moosavi MJ, Shamushaki VAJ (2015) Effects of Different Levels of Copper Sulfate on Growth and Reproductive Performances in Guppy (P. reticulate) J Aquac Res Development 6: 305. doi:10.4172/21559546.1000305

Copyright: (c) 2015 Moosavi MJ, et al. This is an open-access article distributed under the terms of the Creative Commons Attribution License, which permits unrestricted use, distribution, and reproduction in any medium, provided the original author and source are credited. 
put in aquariums to act as shelters for new born offsprings from predation by parents.

In this study, five levels - one as blank and four as experimental groups - of copper sulfate penta-hydrate $\left(\mathrm{CuSO}_{4} 5 \mathrm{H}_{2} \mathrm{O}\right.$, Merck, Germany) concentrations including 0 (as control), 0.004, 0.013, 0.019 and $0.026 \mathrm{mg} \mathrm{CuSO}_{4} \mathrm{l}^{-1}$. Prior to start the trial, the mean $96 \mathrm{~h}$

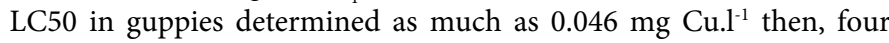
concentrations were selected randomly. According to each level of copper sulfate, selected concentration prepared [12] into four reserved tanks to renew the replaced water volume. All experimental groups have been monitored daily by atomic absorption [13] to ensure the determined concentrations achieved [14].

Acute median lethal concentration (LC50) and their 95\% confidence limits for all tests obtained by Finney's method were calculated with the formula of Mohapatra and Rengarajan. LC50 values of 24, 48, 72 and 96h were determined using Finney's method of probit analysis" and with SPSS computer statistical software. The mean lethal concentration LC50 for an exposure period of 24, 48, 72 and $96 \mathrm{hr}$ was designated by trial and error. Amounts of LC1, LC10, LC30, LC50, LC70, LC90, LC99 were calculated by probit tables, mortality and probit regression.

At the end of the trial, percentage of body Specific Growth Rate (SGR) $[\ln ($ final weight)- $\ln ($ initial weight)/experimental period) $] \times 100$, Feed Conversion Ratio (FCR) [dry feed consumed (g)/gain in wet weight (g) [15], relative fecundity (RF) [absolute fecundity/body weight] [16], Gonadosomatic Index (GSI) [ovary weight/body weight] $\times 100$ [17], Surviving Rate (SR) [final fish number/initial fish number] $\times 100$ [18] and Offspring Production (OP) [new born offspring/number of adult females] calculated.

All data were reported as mean \pm standard deviation. Statistics were performed by using one-way analysis of variance (ANOVA) followed by Duncan multiple comparisons test if significant differences were found. A Kolmogrov-Smirnov test was used to assess normality of distribution and abnormal data were log transformed. Significance was set at $\mathrm{P}<0.05$ level.

\section{Results and Discussion}

Liver, brain, heart, kidney, and muscle are the main storing places for copper; in tissues and blood cells, it bounds to proteins, including many enzymes. It exerts a wide range of physiological effects on vital), and other hematopoietic tissues in which threats the present fishes in area [19]. Copper sulfate toxicity differs among fish species [20]; For

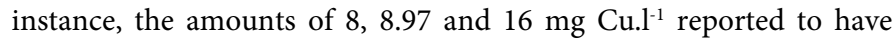
negative effects on tilapia (Oreochromis niloticus $\times$ O-aureus), grupper (Epinephelus malabaricus) and channel catfish (Ictalurus punctatus) respectively $[21,22]$.

In 8 weeks, toxic effects of copper sulfate exposure were recorded (Table 1). As seen, the best growth performance resulted in control group $\left(0 \mathrm{mg} \mathrm{CuSO}{ }_{4} \cdot 1^{-1}\right)$ and growth diminished as copper sulfate increased.

Despite the same initial weight, age and feed consumption, rising amounts of copper had negative effects on weight gain, specific growth rate and feed conversion ratio (Figure 1). There are hypothesis for reduction in growth performance including:

1) Intestine tissue interruption [23]: Heavy metals have their special recipients in which act as a stimulator to them. Intestine can be considered as a target tissue for metals. Copper which enter into the intestine can damage the tissue and by means of that, reduces the nutrition intake from intestine. These researchers found out that, the existence of copper sulfate around catfishes reduced their growth performance due to interruption in intestine tissue. Furthermore, copper sulfate decreases the $\mathrm{Zn} \mathrm{[24]} \mathrm{and} \mathrm{Se} \mathrm{[25]} \mathrm{intake} \mathrm{from} \mathrm{intestine.}$

2) High energy consumption for copper detoxification in liver [26] reported that, in freshwater prawn (Macrobrachium rosenbergii) copper usually transported by the haemolymph to other organs primarily hepatopancreas for storage and detoxification. Ignoring the physiological differences, at the same polluted condition (Here by copper sulfate) guppies transfer copper to liver for detoxification and for fulfilling the detoxification process, body needs extra energy which is provided by more food consumption. Lack of energy for other metabolic processes result in low growth performance.

3) Chronic stress [27-29]: Chronic stress reduced the growth too [30]. The increase in blood glucose and cortisol concentrations is known as a general secondary response to stress of fish to toxic effects [31]. Griffin et al. [32] reported that, copper sulfate raised blood cortisol level (as stressor factor) in channel catfish (I. punctatus). These researches showed that the initial signs of stress (cortisol level) decreased consequently as copper sulfate diminished in water. At present study, a combination of three mentioned hypothesis is reliable reason for low growth performance. These results were in accordance with Berntssen et al. [33] on Atlantic salmon (Salmo salar), [34] on channel catfish (I. Punctatus). These researchers noted that increase in copper sulfate lead to low growth in fish.

Copper sulfate also had negative effects on reproduction performance (Table 1). In sensitive species of teleosts, copper adversely affects reproduction and survival from 0.01-0.02 mg Cu. $\mathrm{l}^{-1}$. At present study, surviving rate, gonadosomatic index, relative fecundity and finally offspring production decreased by increase in copper sulfate levels $(\mathrm{P}<0.05)$ and best performance of mentioned factors resulted in control group (with no copper sulfate). Although relative fecundity between first two treatments $\left(0\right.$ and $\left.0.004 \mathrm{CuSO}_{4} \cdot \mathrm{l}^{-1}\right)$ were not analytically significant; but it would be due to rare concentration of experimental treatment $\left(0.004 \mathrm{CuSO}_{4} \cdot \mathrm{l}^{-1}\right)$. Copper may affect reproductive success of fish through disruption of hatch coordination with food availability or through adverse effects on larval fishes. Chronic exposure of representative species of teleosts to low concentrations ( 0.005 to $\left.0.04 \mathrm{mg} . \mathrm{l}^{-1}\right)$ of copper in water containing low concentrations of organic material adversely affects survival and spawning. Dethloff et al. reported that cortisol is released to the blood via stimulation of the Hypathalamo-Pituitary-Adrenal (HPI) axis by heavy metal exposure. Cortisol has depressive effects on a number of immune responses in fish, including phagocytosis and lymphocyte mitogenesis [35]. Despite the valuable role of HPI hormones in reproductive processes of fishes, cortisol hormone which made in response to stress resistance in fish would interrupt HPI hormones. It will be probably the reason for lowering slope gonadosomatic index in response of rise in copper sulfate concentrations.

Pulsford et al. [36] showed that, cortisol restricts the metabolic activities of macrophage and lymphocyte cells which especially spread in kidney and spleen; on one side, negative effects of copper on intestine inhibited absorption of nutrients like electrolytes and fatty acid intake [37]; on the other side, inducing hypertrophy in gill cells [38], blocking calcium transport in gills through interference with chloride cells and ionic and gas exchanges [39] make fishes weak to stand with situation. That's why low survival rate appears in high doses of copper sulfate. 
Citation: Moosavi MJ, Shamushaki VAJ (2015) Effects of Different Levels of Copper Sulfate on Growth and Reproductive Performances in Guppy (P. reticulate). J Aquac Res Development 6: 305. doi:10.4172/21559546.1000305

Page 3 of 4

\begin{tabular}{|c|c|c|c|c|c|}
\hline \multirow{2}{*}{ Parameters * } & \multicolumn{5}{|c|}{ Copper sulfate concentrations (mg CuSO $4^{\left.\cdot I^{-1}\right)}$} \\
\hline & 0 (Control) & 0.004 & 0.013 & 0.019 & 0.026 \\
\hline Initial length (cm) & $3.61 \pm 0.034^{a}$ & $3.58 \pm 0.026^{a}$ & $3.57 \pm 0.014^{a}$ & $3.6 \pm 0.031^{\mathrm{a}}$ & $3.59 \pm 0.04^{a}$ \\
\hline Final length (cm) & $3.76 \pm 0.02^{\mathrm{a}}$ & $3.71 \pm 0.037^{\mathrm{ab}}$ & $3.65 \pm 0.017^{\mathrm{ab}}$ & $3.7 \pm 0.026^{\mathrm{ab}}$ & $3.6 \pm 0.01^{b}$ \\
\hline Initial weight (gr) & $0.36 \pm 0.005^{a}$ & $0.36 \pm 0.017^{a}$ & $0.37 \pm 0.011^{\mathrm{a}}$ & $0.37 \pm 0.023^{a}$ & $0.36 \pm 0.011$ \\
\hline Final weight (gr) & $0.82 \pm 0.023^{a}$ & $0.78 \pm 0.023^{a}$ & $0.72 \pm 0.011^{b}$ & $0.63 \pm 0.005^{c}$ & $0.65 \pm 0.003$ \\
\hline Specific growth rate & $0.91 \pm 0.013^{a}$ & $0.86 \pm 0.02^{\mathrm{a}}$ & $0.71 \pm 0.015^{b}$ & $0.69 \pm 0.041^{b}$ & $0.59 \pm 0.018^{t}$ \\
\hline Feed conversion ratio & $4.36 \pm 0.16^{c}$ & $4.76 \pm 0.065^{\mathrm{bc}}$ & $5.88 \pm 0.00^{\mathrm{b}}$ & $6.62 \pm 0.31^{\mathrm{ab}}$ & $7.88 \pm 0.89^{a}$ \\
\hline Relative fecundity & $56.82 \pm 1.82^{\mathrm{a}}$ & $51.42 \pm 3.52^{\mathrm{a}}$ & $32.45 \pm 1.63^{b}$ & $34.89 \pm 1.51^{b}$ & $25.57 \pm 1.33^{\mathrm{b}}$ \\
\hline Gonadosomatic index & $6.1 \pm 0.115^{\mathrm{a}}$ & $5.61 \pm 0.034^{b}$ & $5.32 \pm 0.005^{c}$ & $5.29 \pm 0.023^{c}$ & $5.31 \pm 0.011$ \\
\hline Surviving rate & $88.88 \pm 2.77^{a}$ & $55.55 \pm 7.34^{b}$ & $52.77 \pm 7.34^{b}$ & $30.55 \pm 10.01^{c}$ & $27.77 \pm 2.77$ \\
\hline Offspring production & $3.88 \pm 0.22^{\mathrm{a}}$ & $3.33 \pm 0.17^{b}$ & $1.94 \pm 0.07^{c}$ & $1.83 \pm 0.096^{c}$ & $1.55 \pm 0.07$ \\
\hline
\end{tabular}

exposure to several concentrations of Cooper

"Mean \pm SD values with different superscript letters within a raw for a parameter are significantly different $(P<0.05)$.

Table 1: The mean results of growth and reproduction performances of guppy ( $P$. reticulate) in response of

\section{Growth performance}

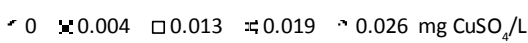

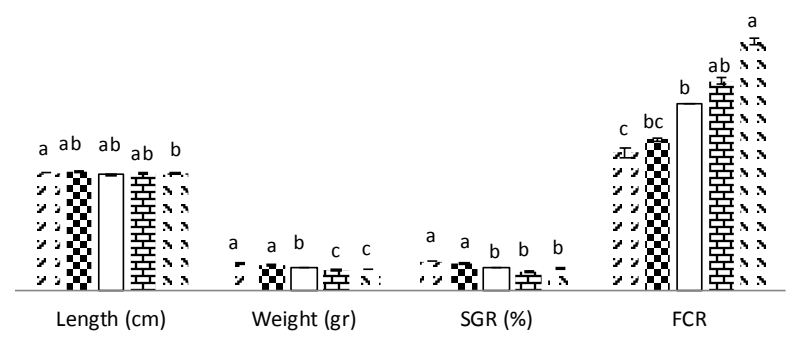

*Different superscript letters within a raw for a parameter are significantly different $(P<0.05)$.

Figure 1: The mean results of growth performance of guppy ( $P$. reticulate) in response of exposure to several concentrations of Cooper during 56 days of trial

\section{Acknowledgments}

Authors thank Gorgan University of Agricultural Science and Natural Resources for laboratory facilities and financial support to carry out this experiment.

\section{References}

1. Lorentzen M, Maage A (1995) Trace element status of juvenile Atlantic salmon Salmo salar L. fed a fish-meal based diet with or without supplementation of zinc, iron, manganese and copper from first feeding Aquaculture Nutrition 5 : 163-171.

2. Perschbacher PW, Wurts WA (1999) Effects of calcium and magnesium hardness on acute copper toxicity to juvenile channel catfish. Ictalurus punctatus Aquaculture. 172: 275-280.

3. Straus DL (2003) The acute toxicity of copper to blue tilapia in dilutions of settled pond water. Aquaculture 219: 233-240.

4. Reddy R, Pillai BR, Adhikari S (2006) Bioaccumulation of copper in postlarvae and juveniles of freshwater prawn Macrobrachium rosenbergii (de Man) exposed to sub-lethal levels of copper sulfate. Aquaculture 252: 356-360.

5. Boyd CE (1990) Water quality in ponds for aquaculture. Alabama Agricultural Experiment Station, Auburn university, Birmingham Publishing.

6. De Oliveira-Filho EC, Lopes RM, Paumgartten FJ (2004) Comparative study on the susceptibility of freshwater species to copper-based pesticides. Chemosphere 56: 369-374.

7. Rábago-Castro J, Sanchez J, Pérez-Castañeda R, González-González A (2006) Effects of the prophylactic use of Romet $(30$ and copper sulfate on growth, condition and feeding indices in Channel catfish (Ictalurus punctatus). Aquaculture 253: $343-349$.

8. Di Giulio RT, Hinton DE (2008) The toxicology of fishes. Taylor and Francis
Group, United States of America.

9. Tucker CC, Robinson EH (1990) Channel catfish farming handbook. Springer.

10. Boyd CE (2005) Copper treatments control phytoplankton Global Aquaculture Advocate.

11. Magurran AE (2005) Evolutionary ecology: the Trinidadian guppy. Oxford University Press.

12. AOAC (2002) Official methods of analysis. (16thedn). Association of Official Analytical Chemists., Arlington, VA, USA.

13. Perkin-Elmer (1964) Analytical methods for atomic absorption spectrophotometry. Corporation, USA.

14. Bruland KW, Franks RP (1979) Sampling and analytical methods for the determination of copper, cadmium, zinc, and nickel at the Nanogram per liter level in sea water. Analytica Chimica Acta 105: 233-245.

15. Yengkokpam S, Sahu N, Pal A, Mukherjee S, Debnath D (2007) Gelatinized carbohydrates in the diet of Catla catla Fingerlings: effect of levels and sources on nutrient utilization, body composition and tissue enzyme activities. Australasian Journal of Animal Sciences 20: 89.

16. Khodadoust A, Rasta M, Khara H, Rahbar M (2013) Determination of Some Biometry and Fecundity Indicators in Female Khramulia (Capoeta capoeta gracilis, Keyserling 1861) in the Sefidroud River. World Journal of Fish and Marine Sciences 5: 392-397.

17. Ling S, Hashim R, Kolkovski S, Chong Shu-Chien A (2006) Effect of varying dietary lipid and protein levels on growth and reproductive performance of female swordtails Xiphophorus helleri (Poeciliidae). Aquaculture Research 37 1267-1275.

18. Lin YH, Shie YY, Kent M, Shiau SY (2010) Dietary copper requirements of juvenile grouper, Epinephelus malabaricus, with an organic copper source. Aquaculture 310: 173-177.

19. Eisler R (1998) Copper hazards to fish, wildlife, and invertebrates: A synoptic review. DTIC Document.

20. Sorensen EM (1991) Metal poisoning in fish. CRC press

21. Gatlin DM, Wilson RP (1986) Dietary copper requirement of fingerling channel catfish Aquaculture 54: 277-285.

22. Shiau S, Ning Y (2003) Estimation of dietary copper requirements of juvenile tilapia, Oreochromis niloticus x O-aureus. Animal Science 77: 287-292.

23. Handy RD (1992) The assessment of episodic metal pollution. II. The effects of cadmium and copper enriched diets on tissue contaminant analysis in rainbow trout (Oncorhynchus mykiss). Arch Environ Contam Toxicol 22: 82-87.

24. Cousins RJ (1985) Absorption, transport, and hepatic metabolism of copper and zinc: special reference to metallothionein and ceruloplasmin. Physiol Rev 65: 238-309.

25. Lorentzen M, Maage A, Julshamn K (1998) Supplementing copper to a fish meal based diet fed to Atlantic salmon parr affects liver copper and selenium concentrations. Aquaculture Nutrition 4: 67-72.

26. Slatinská I, Smutná M, Havelková M, Svobodová Z (2008) Review article: 
Citation: Moosavi MJ, Shamushaki VAJ (2015) Effects of Different Levels of Copper Sulfate on Growth and Reproductive Performances in Guppy (P. reticulate). J Aquac Res Development 6: 305. doi:10.4172/21559546.1000305

biochemical markers of aquatic pollution in fish - glutathione s-transferase. Folia veterinaria 52: 129-134.

27. Dethloff GM, Schlenk D, Khan S, Bailey HC (1999) The effects of copper on blood and biochemical parameters of rainbow trout (Oncorhynchus mykiss). Arch Environ Contam Toxicol 36: 415-423.

28. Rawles S, Kocabas A, Gatlin DM, Du W, Wei C (1998) Dietary Supplementation of Terramycin and Romet-30 Does Not Enhance Growth of Channel Catfish But Does Influence Tissue Residues. Journal of the World Aquaculture Society 28: 392-401.

29. Truchot J, Rtal A (1998) Effects of long-term sublethal exposure to copper on subsequent uptake and distribution of metal in the shore crab Carcinus maenas. Journal of Crustacean Biology.

30. Kjartansson H, Fivelstad S, Thomassen JM, Smith MJ (1988) Effects of different stocking densities on physiological parameters and growth of adult Atlantic salmon (Salmo salar L.) reared in circular tanks. Aquaculture 73: 261-274.

31. Farat O, Cogun HY, Yuzereroglu TA, Gok G, Firat O, et al. (2011) A comparative study on the effects of a pesticide (cypermethrin) and two metals (copper lead) to serum biochemistry of Nile tilapia, Oreochromis niloticus. Fish Physiol Biochem 37: 657-666.

32. Griffin BR, Davis KB, Schlenk D (1999) Effect of simulated copper sulfate therapy on stress indicators in channel catfish. Journal of Aquatic Animal Health 11: 231-236.

33. Berntssen MH, Lundebye AK, Maage A (1999) Effects of elevated dietary copper concentrations on growth, feed utilisation and nutritional status of Atlantic salmon (Salmo salar L.) fry. Aquaculture 174: 167-181.

34. Murai T, Andrews JW, Smith Jr RG (1981) Effects of dietary copper on channel catfish. Aquaculture 22: 353-357.

35. Harris J, Bird DJ (2000) Modulation of the fish immune system by hormones Vet Immunol Immunopathol 77: 163-176.

36. Pulsford A, Crampe M, Langston A, Glynn P (1995) Modulatory effects of disease, stress, copper, TBT and vitamin E on the immune system of flatfish. Fish and Shellfish Immunology 5: 631-643.

37. Irianto A, Austin B (2002) Probiotics in aquaculture. Journal of Fish Diseases 25: 633-642.

38. Van Heerden D, Vosloo A, Nikinmaa M (2004) Effects of short-term copper exposure on gill structure, metallothionein and hypoxia-inducible factor-1alpha (HIF-1alpha) levels in rainbow trout (Oncorhynchus mykiss). Aquat Toxicol 69: 271-280.

39. Evans DH (1987) The fish gill: site of action and model for toxic effects of environmental pollutants. Environ Health Perspect 71: 47-58. 